\title{
Модель цирозу та печінкової енцефалопатії у щурів
}

\author{
Е. Г. Манжалій ${ }^{1}$, Т. М. Фалалєева ${ }^{2}$, О. Б. Динник ${ }^{3}$, О. В. Вірченко ${ }^{2}$, В. Є. Кондратюк ${ }^{1}$, \\ О. Г. Курик ${ }^{4}$, Т. В. Берегова ${ }^{2}$
}

${ }^{1}$ Національний медичний університет імені О. О. Богомольця МОЗ України, м. Київ, ${ }^{2}$ Київський національний університет імені Тараса Шевченка МОН України, ${ }^{3}$ Інститут еластографії, м. Київ,

${ }^{4}$ Науково-практичний центр профілактичної та клінічної медицини, м. Київ

\section{Pattern of cirrhosis and hepatic encephalopathy in rats}

\author{
E. G. Manzhalii ${ }^{1}$, T. M. Falalyeyeva ${ }^{2}$, O. B. Dynnyk ${ }^{3}$, O. V. Virchenko ${ }^{2}$ V. E. Kondratiuk ${ }^{1}$, \\ O. G. Kuryk ${ }^{4}$, T. V. Beregova ${ }^{2}$ \\ ${ }^{1}$ Bogomolets National Medical University, Kyiv, \\ ${ }^{2}$ Taras Shevchenko National University of Kyiv, \\ ${ }^{3}$ Institute of Elastography, Kyiv, \\ ${ }^{4}$ Scientific-Practical Centre of Prophylactic and Clinical Medicine, Kyiv
}

\section{Реферат}

Мета. Покращити моделювання цирозу печінки (ЦП), ускладненого печінковою енцефалопатією (ПЕ), у щурів та порівняти результати діагностики цих патологій на основі вироблення харчового умовного рефлексу, гістологічного аналізу тканини печінки та зсувнохвильової еластографії (3ХЕ) цього органу.

Матеріали і методи. Оцінка розвитку ПЕ проведена на моделі вироблення харчового умовного рефлексу в Т-подібному лабіринті. Для підтвердження розвитку ураження печінки оцінено гістологічний стан органу та виміряно його жорсткість в кПа методом 3ХЕ.

Результати. За умов введення чотирихлористого вуглецю $\left(\mathrm{CCl}_{4}\right)$ у щурів погіршуються когнітивні показники, порушується вироблення умовного рефлексу, щурі частіше помиляються, вибираючи шлях до харчового підкріплення. На основі даної методики можна судити про розвиток ПЕ у щурів. Ураження печінки підтверджене даними гістологічного аналізу та збільшенням жорсткості печінки, зафіксованим при 3ХЕ, більше ніж у 4 рази. У тварин констатовано розвиток фіброзу та цирозу печінки.

Висновки. Покращено моделювання та діагностику ПЕ та ЦП у щурів. Підтверджена висока діагностична цінність 3ХЕ печінки. Метод є чутливим, що дає можливість замінити ним біопсію печінки.

ключові слова: печінкова енцефалопатія; цироз печінки; гістологія; еластографія печінки.

Abstract

Objective. To improve the hepatic cirrhosis course, complicated by hepatic encephalopathy (HE), simulation procedure in rats was conducted to compare the diagnosis results of these pathologies, basing on elaboration of alimentary conditioned reflex, histological analysis of hepatic tissue and shear wave elastography (SHWE) data of this organ.

Materials and methods. Estimation of development of HE was conducted on the simulation model with elaboration of alimentary conditioned reflex in a T-like labyrinth. Histological state of the organ and its rigidity in kPa measured, using method of SHWE, were estimated to confirm the hepatic affection development.

Results. While use of carbon tetrachloride $\left(\mathrm{CCl}_{4}\right)$ in rats the cognitive indices worsen, disordering elaboration of conditioned reflex; rats are mistaken, choosing the way to alimentary confirmation. Basing on this method it is possible to discuss issue about development of HE in rats. Hepatic affection was confirmed by data of histological analysis and hepatic rigidity enhancement, registered by SHWE, more than in 4 times. In the patients development of hepatic fibrosis and cirrhosis was postulated. Conclusion. Simulation and diagnosis of HE in hepatic cirrhosis in rats was improved. High diagnostic validity of hepatic SHWE was confirmed. The method is sensitive, making possible to replace hepatic biopsy.

Keywords: hepatic encephalopathy; hepatic cirrhosis; histology; hepatic elastography.

У сучасній науковій літературі наведені результати експериментальних досліджень та накопичений фактичний матеріал щодо моделей ПЕ при захворюваннях печінки. Але точного прототипу моделювання ПЕ немає у зв'язку, зокрема, зі значною смертністю тварин внаслідок ускладнень ЦП. Нині дослідники пропонують модель ПЕ, де як хімічну сполуку використовують $\mathrm{CCl}_{4}$ в поєднанні 3 вазеліновою олією у співвідношенні 1:1, що вводиться одноразово щотижня протягом 4 - 6 тиж. ПЕ діагностується за наявністю вираженого дистрофічного процесу гепатоцитів, у судинній системі і жовчних протоках портальних трактів. Зміни функціонування мозку були вивчені на моделі формування харчового умовного рефлексу: після моделювання ПЕ у щурів було виявле- но збільшення часу добігання до харчового підкріплення (іжі) на відстань 30 см по прямій лінії до 100 - 150 с (патент RU 2363990). Але за даної моделі вивчення ПЕ не зрозуміло, збільшення часу добігання щурів до їжі пов'язане з порушенням мислення чи із загальною загальмованістю мозкових процесів та зниженою руховою активністю. Тому актуальною є розробка моделі діагностики ПЕ, в якій враховуються зміни показників основних когнітивних функцій у щурів: мислення, навчання та запам'ятовування. Більш того, застосування даної моделі в наших експериментах призводило до значного рівня летальності серед лабораторних тварин, що ускладнювало планування досліджень. У зв'язку з цим нами була застосована модель внутрішньоочеревинного (в/о) введення 
0,75 мл/кг 15\% розчину $\mathrm{CCl}_{4}$. За даної схеми використовувалася менша доза тетрахлорметану, тому термін моделювання ЦП зростав до 8 тиж., що суттево збілышувало тривалість експерименту, але разом з тим зменшувало показники летальності. Тому одним із завдань нашого дослідження було покращити модель ЦП на щурах шляхом незначного збільшення дози $\mathrm{CCl}_{4}$ та частоти введення, щоб забезпечити розвиток патології за коротший час 3 мінімальною смертністю тварин у ході експерименту. Іншим важливим питанням залишалася оцінка ефективності моделювання ЦП у щурів.

Одним із основних діагностичних методів $є$ гістологічне дослідження, що дозволяє уточнити причину захворювання печінки, а також оцінити індекс гістологічної активності. Проте метод має об'єктивні недоліки: інвазивність, складність підготовки, больові відчуття в місці проколу, ускладнення (кровотеча, гемоперитоніум, біліарний перитоніт, пневмоторакс). Також можлива смертність, хоча й з низькою ймовірністю - 0,001 0,003\%. Більш того, біоптат є нерепрезентативним через помилки влучання, адже тканина печінки нерівномірно уражена: можна взяти випадково пробу, аналіз якої буде свідчити про більш сильне або, навпаки, слабкіше ураження печінки, ніж є насправді. Крім об'єктивних, є й суб'єктивні недоліки, пов'язані з необхідністю достатньої кваліфікації морфолога, який повинен отримати адекватний об'єм біоптату із захопленням не менше 11 портальних трактів, а також високою варіабельністю в трактуванні результатів. Ця інвазивна процедура не може бути застосована для скринінгового обстеження пацієнтів та динамічного моніторингу ефективності терапії, що проводиться при різних дифузних захворюваннях печінки. У зв'язку з викладеним актуальною є неінвазивна діагностика стану печінки, зокрема, застосування методу 3XЕ [1]. Цей метод має ряд переваг: безпечність для пацієнта, висока інформативність на будь-якій стадії фіброзу, своєчасне виявлення ранніх стадій хвороби, просте виконання, використання скринінгу в групах ризику та відносно невисока вартість.

Метод еластографії був успішно застосований на щурах та дозволив визначити жорсткість печінки [2]. Тому нас зацікавило порівняння ефективності методу еластографії печінки та гістологічного аналізу у діагностуванні ураження печінки щурів, викликаного введенням $\mathrm{CCl}_{4}$.

Мета роботи: покращити моделювання ЦП, ускладненого ПЕ, у щурів та порівняти результати діагностики цих патологій на основі вироблення харчового умовного рефлексу, гістологічного аналізу тканини печінки та ЗХЕ цього органу.

\section{Матеріали і методи дослідження}

Дослідження проведено на 16 щурах-самцях згідно 3 нормативами Європейської конвенції про захист хребетних тварин, які використовуються для експериментальних та інших наукових цілей, загальними етичними принципами експериментів на тваринах, ухваленими Першим національним конгресом України з біоетики (вересень 2001 року), іншими міжнародними угодами та національним законодавством у цій галузі. Тварин утримували в умовах акредитованого віварію згідно зі
«Стандартними правилами по упорядкуванню, устаткуванню та утриманню експериментальних біологічних клінік (віваріїв)».

Тварини були розділені на дві групи по 8 у кожній: перша - інтактні тварини, друга - дослідні щури, яким моделювали цироз і ПЕ і проводили еластографію печінки для підтвердження фіброзу. Після чого тварин умертвляли гуманним чином та видаляли печінку. 3 кожної печінки вирізали 2 - 3 шматочки для морфологічного аналізу та одразу фіксували у $10 \%$ розчині формаліну. Після фіксації поміщали у гістопроцесор карусельного типу STP-120. Станцію EC-350 використовували для заливки препаратів парафіном. Для отримання гістологічних зрізів використаний ротаційний мікротом НM-340Е. Фарбували препарати за допомогою автомата Robot-Stainer HMS-740 гематоксиліном та еозином, потім досліджували під мікроскопом Axioskop 40.

Гістологічні мікропрепарати досліджували світлооптично та морфометрично. Визначали діаметр гепатоцитів, діаметр їх ядер, ядерно-цитоплазматичні відношення, стромально-паренхіматозне відношення в досліджуваних клітинах печінки, відносний об'єм ушкоджених гепатоцитів.

Для моделювання експериментальної ПЕ тваринам другої групи вводили в/о 1 мл/кг $15 \%$ розчину $\mathrm{CCl}_{4}$ в оливковій олії чотири рази на тиждень впродовж 4 тиж. Всі тварини мали вільний доступ до води та їжі. Після закінчення введення розчину $\mathrm{CCl}_{4}$ досліджували порушення роботи мозку (розвиток ПЕ) на моделі вироблення харчового умовного рефлексу, мислення, навчання та запам'ятовування.

У тварин оцінювали швидкість формування харчового умовного рефлексу в Т-подібному лабіринті, яку визначали, фіксуючи час від моменту входження тварин в Т-подібний лабіринт до моменту знаходження їжі в лівому рукаві лабіринту та початку їди.

Для отримання відтворюваного результату здійснювали такі маніпуляції. За тиждень до початку вироблення харчового умовного рефлексу до стандартного корму щурів додавали сир, щоб тварини звикли до такої їжі. Під час дослідження у лабіринті щурів тримали на легкому голоді - давали корм з розрахунку 15 г комбікорму на щура масою 250 г при нормі 20 - 30 г. Під час експерименту щура саджали в центральну частину лабіринту, оточену стінками, та розпочинали відлік часу. Через певний час щур знаходив вихід 3 центральної частини у П-подібний коридор, що мав два рукави - лівий і правий. В кінці лівого рукава знаходилася їжа (декілька кубиків сиру загальною масою 30 г). Реєстрували час у секундах, коли тварина знаходила сир (підбігала до нього) та час, коли починали їсти (до харчового підкріплення). Другий часовий показник був обраний для порівняння. Після знаходження їжі тварині дозволяли їсти впродовж 30 с, тобто не вилучали щура з лабіринту одразу після початку їди, що частково зменшувало стрес та негативні асоціації у тварин, пов'язані з годівлею в лабіринті. Оцінювали запам'ятовування щурів, у якому рукаві знаходиться їжа, за кількістю помилкових поворотів у правий рукав. Спостерігали за виробленням харчового умовного рефлексу впродовж 14 днів. Оцінювали динаміку зміни часу від входження тварин обох груп у лабі- 
ринт до початку їди, а також порівнювали час до харчового підкріплення у щурів двох груп на 14-ту добу експерименту.

Оцінено еластичність та ступінь фіброзу печінки з використанням методики 3XE на ультразвуковому сканері Ultima ${ }^{\circledR}$ (фірма «Радмир», Україна) із застосуванням лінійного мультичастотного датчика 5 - 12 МГц. Прилад оснащений модулем еластографії, робота якого заснована на новому принципі реєстрації поперечних зсувних хвиль (Shear Wave). Ступінь фіброзу паренхіми печінки оцінювали за шкалою Metavir. 3XE здійснювали 3 вивченням кількісних та якісних показників жорсткості печінкової тканини в правій та лівій частках, виміряної в кПа та продемонстрованої на знімках кольоровим кодуванням.

\section{Результати}

Простежені динаміка формування у щурів харчового умовного рефлексу, час від виходу з центральної частини Т-подібного лабіринту до початку харчового підкріплення. Критерієм вироблення умовного харчового рефлексу було швидке та безпомилкове знаходження тваринами правильного шляху в лабіринті. Із 7-ї доби від початку експерименту інтактні щури швидше знаходили їжу та починали їсти. Хоча час, за який щури діставалися до підкріплення, скорочувався вже на 3-тю добу: тварини швидко підбігали до їжі, потім перебігали у правий рукав і лише через 60 - 180 с починали їсти (див.puсунок).

Введення $\mathrm{CCl}_{4}$, що супроводжується токсичним впливом на функціонування печінки, призводило до суттєвого погіршення мислення, навчання та запам'ятовування у щурів. Послаблення когнітивних процесів було зареєстровано вже на 1-шу добу від початку експерименту. Час до харчового підкріплення становив (334 \pm 50$)$ с, що було в 2,1 разу ( $<$ 0,05) більше за відповідний показник у інтактних щурів. Впродовж усіх 14 діб експерименту не виявлено позитивної динаміки скорочення часу від входження в лабіринт до харчового підкріплення. На 14-ту добу від початку вироблення харчового умовного рефлексу час до знаходження їжі і початку їди у щурів з $\mathrm{CCl}_{4}-$ індукованим цирозом перевищував показники контролю в 21,4 разу ( $\mathrm{p}<0,001)$. Описана методика вироблення харчового умовного рефлексу дає можливість підтвердити розвиток когнітивних порушень та прогресування ПЕ у щурів з $\mathrm{CCl}_{4}$-асоційованим ураженням печінки. Проте дані неврологічного тестування не дають можливості оцінити ступінь ушкодження органу та прогресування цирозу. Тому на наступному етапі ми порівняли дві методики оцінки стану печінки: неінвазивну - еластографію та інвазивну - гістологічний аналіз органу.

Гістологічне дослідження $€$ «золотим стандартом» оцінки ступеня фіброзу та розвитку цирозу. Контрольна група тварин мала нормальну гістологічну будову печінки. Трабекули гепатоцитів були розташовані чітко радіально відносно портальних трактів, капіляри в печінкових часточках мали нормальний розмір, гепатоцити були нормального розміру без включень в цитоплазмі. У групі тварин, яким вводили $\mathrm{CCl}_{4}$, був продемонстрований розвиток ЦП. На мікропрепаратах тканини органу відмічали розростання фіброзної тканини з формуванням несправжніх часточок. Була чітко виражена дифуз-

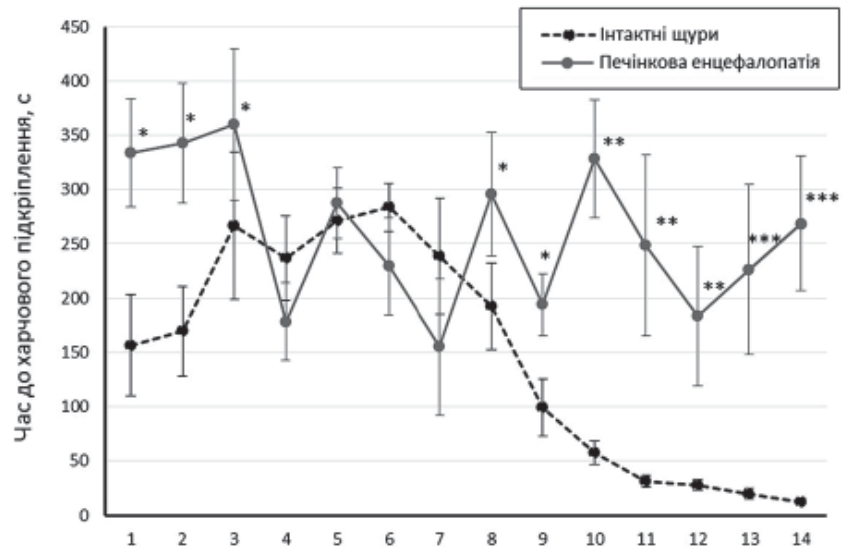

Час до харчового підкріплення в динаміці в процесі вироблення харчового умовного рефлексу за умов моделювання иирозу печінки, викликаного введенням $\mathrm{CCl}_{4}$ $(n=7, \bar{x} \pm m) . " p<0,05,{ }^{* * *} p<0,05,{ }^{* * *} p<0,05-$ порівняно з показниками в інтактних тварин відповіднӧ̈дби експерименту.

на великокрапельна жирова дистрофія гепатоцитів, реєстрували лейкоцитарну інфільтрацію в паренхімі печінки, повнокров'я судин. Гістологічний аналіз підтвердив порушення морфофункціональної цілісності тканини печінки.

Стан печінки був кількісно оцінений за морфометричними показниками та за шкалою Knodell, за якою показано високу активність фіброзу з переходом у цироз у щурів після введення $\mathrm{CCl}_{4}$ (табл. 1).

Застосування неінвазивного методу ЗХЕ також підтвердило суттєві зміни в печінці щурів, яким вводили $\mathrm{CCl}_{4}$ (mабл. 2). Отримані показники жорсткості печінки свідчать про розвиток цирозу в експериментальній групі тварин (стадія $\mathrm{F}_{4}$ за шкалою Metavir).

\section{Обговорення}

У щурів з індукованим ураженням печінки не вдавалося викликати формування харчового умовного рефлек-

\begin{tabular}{|c|c|c|c|}
\hline Таблиця 1. & \multicolumn{3}{|c|}{$\begin{array}{l}\text { Оцінка стану печінки у щурів } \\
\text { з ССl } 4 \text {-індукованим ураженням печінки } \\
\text { на основі морфометричних показників } \\
\text { та за шкалою Knodell } \\
(\bar{x} \pm \mathrm{m})\end{array}$} \\
\hline \multicolumn{3}{|r|}{ Інтактні тварини } & $\begin{array}{c}\text { Щури з } \mathrm{CCl}_{4-} \\
\text { індукованим } \\
\text { ураженням } \\
\text { печінки }\end{array}$ \\
\hline \multicolumn{2}{|c|}{$\begin{array}{l}\text { Об'єм пошкоджених } \\
\text { гепатоцитів }\end{array}$} & $4,06 \pm 0,66$ & $66,74 \pm 5,48 * *$ \\
\hline \multicolumn{2}{|c|}{$\begin{array}{l}\text { Стромально- } \\
\text { паренхіматозне } \\
\text { співвідношення }\end{array}$} & $0,142 \pm 0,015$ & $0,224 \pm 0,020 *$ \\
\hline \multicolumn{2}{|c|}{$\begin{array}{l}\text { Ядерно-цитоплазматичне } \\
\text { співвідношення }\end{array}$} & $0,212 \pm 0,008$ & $0,120 \pm 0,004^{*}$ \\
\hline \multicolumn{2}{|c|}{$\begin{array}{l}\text { Фіброз, бали за шкалою } \\
\text { Knodell }\end{array}$} & - & $3,6 \pm 0,2^{*}$ \\
\hline \multicolumn{2}{|c|}{$\begin{array}{l}\text { активності за шкалою } \\
\text { Knodell }\end{array}$} & - & $13,2 \pm 0,7^{*}$ \\
\hline Примітка. & \multicolumn{3}{|c|}{$\begin{array}{l}* \text { - } p<0,05, * * \text { - } p<0,001 \text { порівняно } \\
\text { з інтактними щурами. Те ж у табл. } 2 .\end{array}$} \\
\hline
\end{tabular}




\begin{tabular}{|c|c|c|c|}
\hline \multirow[t]{2}{*}{ Таблиця 2.} & \multicolumn{3}{|c|}{$\begin{array}{l}\text { Оцінка стану печінки у щурів } \\
\text { з ССІ } \\
\text { метондукованим ураженням печінки } \\
\text { еластографії }\end{array}$} \\
\hline & ник & $\begin{array}{l}\text { Інтактні } \\
\text { тварини }\end{array}$ & $\begin{array}{c}\text { щури з } \mathrm{CCl}_{4-} \\
\text { індукованим } \\
\text { ураженням } \\
\text { печінки }\end{array}$ \\
\hline \multicolumn{2}{|c|}{$\begin{array}{l}\text { Жорсткість печінки, } \\
\text { кПа }(\bar{x} \pm m)\end{array}$} & $4,63 \pm 0,94$ & $22,18 \pm 3,85^{*}$ \\
\hline \multicolumn{2}{|c|}{$\begin{array}{l}\text { Стадія фіброзу за шкалою } \\
\text { Metavir }\end{array}$} & $\mathrm{F}_{0}$ & $\mathrm{~F}_{4}$ \\
\hline
\end{tabular}

су. Тварини не були здатні запам'ятати, в якій частині лабіринту знаходиться їжа, були в цілому загальмовані та протягом всього експерименту знаходили їжу не швидше, ніж на початку дослідження. Тому тестування щурів у лабіринті дозволяє більш чітко встановити когнітивні порушення, а відповідно розвиток ПЕ, ніж просто вивчення часу добігання до харчового підкріплення по заданому шляху, як це робили інші дослідники. Згідно з даними літератури введення $\mathrm{CCl}_{4}$ не викликало чітко вираженої ПЕ у щурів, призводило до високої смертності та сильного асциту, що ускладнювало інтерпретацію даних [3]. Возночас маємо більш нові дані, які підтверджують подальше застосування $\mathrm{CCl}_{4}$ як хімічного агента, що викликає ураження печінки [4]. Це дає можливість стверджувати, що успішне моделювання ПЕ залежить від правильно підібраної дози, частоти та тривалості введення $\mathrm{CCl}_{4}$, що й було успішно досягнуто в нашому дослідженні. Ураження печінки були оцінені гістологічно та із застосуванням методу еластографіі. Показники жорсткості печінки підтверджували висновки гістологічного аналізу, що вказує на діагностичну цінність даного методу, проте вони варіювали в широкому діапазоні. Більш того, одна тварина з експериментальної групи мала жорсткість печінки менше 10 кПа. В даному випадку без додаткового гістологічного аналізу немає можливості чітко діагностувати ураження печінки.

Отже, отримані дані дають підстави стверджувати, що чутливість методу еластографії становить 87,5\% порів- няно з гістологічним аналізом, що є відмінним результатом. Просте застосування, доступність, неінвазивність і можливість дослідження у всіх відділах печінки робить метод перспективним для застосування в діагностиці активності фіброзу печінки [5].

\section{Висновки}

1. На основі оцінки формування харчового умовного рефлексу у щурів з ураженням печінки досягнуто покращення діагностики ПЕ.

2. Тканину печінки при ЦП оцінювали шляхом проведення гістологічного аналізу та застосування неінвазивного методу 3ХЕ, що дало змогу констатувати наявність фіброзу та цирозу печінки.

3. На основі порівняння отриманих результатів зроблено висновок про високу ефективність методу еластографії для оцінки фіброгенезу при захворюваннях печінки у щурів, високу чутливість та можливість бути альтернативою біопсії.

\section{References}

1. Bodnar P, Dynnyk O, Myhalchyshyn G. Diagnosis of experimental stetohepatosis using ultrasound shear wave elastography. Current Issues in Pharmacy and Medical Sciences. 2013;26(1):109-13. 10.1515/ cipms-2017.

2. Dynnyk OB, Berezovsky VA, Kobyliak NM, Litovka IG, Yanko RV, Plotnikova LN. Determination of age-related liver stiffness changes in rats according to the ultrasonic shear wave elastography. Fiziol $\mathrm{Zh}$. 2013;59(3):111-8. [In Ukrainian]

3. Díaz-Gómez D, Jover M, del-Campo JA, Galindo A, Romero-Gómez M. Experimental models for hepatic encephalopathy. Rev Esp Enferm Dig. 2011 Oct:103(10):536-41.

4. Owada Y, Tamura T, Tanoi T, Ozawa Y, Shimizu Y, Hisakura K, et al. Novel non-alcoholic steatohepatitis model with histopathological and insulin-resistant features. Pathol Int. 2018 Jan;68(1):12-22. doi: $10.1111 /$ pin. 12612 .

5. Langdon JH, Elegbe E, Gonzalez RS, Osapoetra L, Ford T, McAleavey SA. Measurement of Liver Stiffness Using Shear Wave Elastography in a Rat Model: Factors Impacting Stiffness Measurement with Multiple- and Single-Tracking-Location Techniques. Ultrasound Med Biol. 2017 Nov;43(11):2629-39. doi: 10.1016/j.ultrasmedbio.2017.07.004. 